discovery of a mosaic floor of a previously unknown type, are accompanied by the welcome announcement that the Corporation of St. Albans has decided that the site shall be a permanent exhibition of the excavation, and parts of the structures discovered have been prepared for inspection accordingly, while the Office of Works is maintaining the South Tower with its ditches as an example of the system of defences of the second Roman city. At Colchester, where the Excavation Committee is at work on land adjoining Sheepen Farm, has been found a grave group, concluded to be that of a wealthy RomanoBritish lady and dated at the middle of the second century A.D., which has afforded some remarkable examples of Romano-British artistry and technique. According to the report which appeared in the Times of August 14, the grave group, which was enclosed in a large globular amphora, included a two-handled cinerary urn, a square metal mirror, a bronze brooch, another brooch with an unusual decoration of bone or ivory knobs, and a casket containing beads, pins, rings and other small objects. Most notable, however, among the contents of the amphora was a vase of Castor ware, with a lid, about three inches high, with a decorative design of a man fighting a lion and hounds chasing stags. The whole is executed in the technique of applied clay paste known as barbotine, which is known to have sprung up in the second century A.D. This is not only the finest, but also the earliest dated example of this form of RomanoBritish art. A large deposit of glass vessels has also been found. It may be that the excavators are on the track of a local factory of the large amount of glass which has been found at Colchester; but up to the present no sign of a kiln has appeared.

\section{Reductions of Scientific Staffs in the United States}

A RECENT drastic reduction by the United States Federal Government of $27 \cdot 3$ per cent in the funds appropriated by Congress for the Bureau of Mines involves the dismissal or placing on indefinite furlough of 25-30 per cent of the present staff including about 70 members of its scientific or technical personnel. The health division of the Bureau is being abolished and the officers assigned to it from the public health service are being returned to the Service. The helium division is being merged with the petroleum and natural gas division, and all the field offices and stations of the Bureau are affected to varying degrees. Little relief will accrue to Federal scientific research funds from the recent assignments of public works funds. The latter are aimed at putting unemployed labour to work and not at restoring to fruitful research activities the large number of scientific workers who have suffered under the economy 'axe'. The $4 \frac{1}{4}$ million dollars allotted to scientific bureaux from the public works funds are largely to be expended on reconditioning buildings in which the laboratory work has been severely restricted. The situation is all the more serious because of the extent to which the continued depression has diminished the income and resources from foundations or endowments available for scientific and creative educational work.

\section{Business Administration}

The close of the second teaching year in the Department of Business Administration at the London School of Economics marks the successful completion of a further stage in training for business management and the beginning of a new and important development in the recruiting of trained men to industry and commerce. The Department has faced two main problems: on one hand, the framing of courses which would give training suitably specialised in business subjects and at the same time develop the discipline and judgment required for handling practical problems; on the other hand, to attract students of the right type and quality in sufficient numbers. Satisfactory progress has been made in dealing with the first problem. The specialised business subjects which form the Department's main course comprise marketing, production, finance, statistics, accounting and personnel management as instruments of executive control. The Department has broken the greatest amount of new ground in the fields of marketing, retail management and sales management, where the teaching is based on investigations of current practice and where it is hoped to extend these systematic investigations to cover other major fields of business activity. Special efforts are made to keep the teaching in close touch with practice through discussions opened by business men, visits to factories, shops and offices, and the use in the marketing courses of the case method.

DURING the past two years nearly forty students have been trained by the Department of Business Administration, half in the specialised business course, and half in the preliminary evening course. Most of the students were university graduates, and nearly all were between 22 and 28 years of age. About half of these students were seconded for training by associated firms and at the end of each session there was a keen demand for the non-seconded students from firms wishing to recruit trained men. A further step to secure an adequate supply of suitable students has now been taken by the Department and it is expected that in future students will be drawn mainly from the universities rather than by seconding from industrial firms. Eight or ten firms associated with the Department are offering definite positions to men selected by them and trained by the Department. Candidates must possess a university degree and high personal qualifications and must themselves defray the cost of the Department's specialised business course. On the completion of their training they will be assured of definite posts at salaries arranged in advance, and this university scheme thus offers the right man a new and notable opportunity. It should further assist towards the gradual raising of the general level of business administration.

\section{The Engineer and Public Affairs}

Ar a joint meeting of Engineering and Economic Societies, recently held in Chicago, Dean Dexter $\mathbf{S}$. Kimball of Cornell University College of Engineering 